\title{
УДК 635.7
}

DOI: $10.31563 / 1684-7628-2019-51-3-6-9$

И.Е Анищенко, О.Ю. Жигунов, Л.М. Ишбирдина

\section{НЕКОТОРЫЕ МАЛОИСПОЛЬЗУЕМЫЕ ПРЯНО-АРОМАТИЧЕСКИЕ РАСТЕНИЯ В БАШКИРСКОМ ПРЕДУРАЛЬЕ}

\section{Ключевые слова: пряно-ароматические растения; морфометрические параметры; сезонный ритм развития; успешность интродукции.}

Введение. Пряно-ароматические растения известны человеку с древних времен. Потребность в пряно-ароматических растениях до сих пор постоянно растет. Они необходимы в различных отраслях промышленности (косметической, парфюмерной, фармацевтической), и прежде всего - в пищевой. Это связано с наличием в них минеральных солей, витаминов, эфирных масел, гликозидов, терпенов, терпеноидов и др. соединений. Пряности улучшают вкус пищевых продуктов [1]. Республика Башкортостан отличается богатством и разнообразием растительности. Более 200 видов дикорастущих растений республики представляют интеpec с точки зрения использования их в качестве лекарственного и пряно-ароматического сырья. Интродукционное изучение местных и инорайонных растений позволяет выявить биологические особенности растений, изучить ритм развития и рекомендовать наиболее перспективные виды для выращивания в Башкирском Предуралье. Особой популярностью пользуются такие пряные растения семейства Apiaceae Lindl. (Сельдерейные), как петрушка, укроп, кориандр, сельдерей, фенхель и др. Но это семейство содержит не менее ценные, к сожалению, еще малоиспользуемые виды, такие как Silaum silaus (L.) Schinz et Thell (морковник обыкновенный) и Levisticum officinale Koch. (любисток лекарственный).

Цель исследований - изучение особенностей сезонного ритма роста и развития, морфометрических показателей и оценки успешности интродукции двух малоиспользуемых пряноароматических видов семейства Apiaceae Silaum silaus и Levisticum officinale в условиях культуры.

Условия и методы исследований. Исследования проводились в Южно-Уральском ботаническом саду с 2001 г.

Климат г. Уфы континентальный, характерный для северных лесостепей. Среднегодовая температура воздуха $+3,8^{\circ} \mathrm{C}$, а сумма осадков -
589 мм. Отрицательные средние месячные температуры характерны для пяти месяцев в году, отдельные заморозки возможны во все месяцы, кроме июля и августа. Средняя январская температура $-14,6^{\circ}$. Абсолютный минимум $-54^{\circ}$. Средняя температура июля равна $19^{\circ}$, абсолютный максимум достигает $40^{\circ}$. Безморозный период длится около 140 дней [3].

В работе нами использованы методики И.Н. Бейдеман [4], Н.В. Трулевич [5], статистическая обработка фактического материала проведена по Г.Н. Зайцеву [6], оценка успешности интродукции по Р.А. Карписоновой [7] и Л.И. Томиловой [8].

Результаты исследований. Изученные виды имеют большое пищевое значение и обладают лечебными свойствами благодаря наличию в своем составе эфирных масел, флавоноидов, алкалоидов, витаминов, кумаринов и др. Морковник положительно влияет на систему кровообращения, мочевыделительную систему, обладает тонизирующим, противовоспалительным и общеукрепляющим действием. Любисток имеет желчегонное, седативное, спазмолитическое, антибактериальное действие, улучшает пищеварение [2].

Способность прохождения полного цикла сезонного развития изучаемого вида растений является основным критерием успешности его интродукции. Весеннее отрастание у Silaum silaus и Levisticum officinale происходит в конце апреля, в фазу бутонизации растения вступают во второй декаде июня, массовое цветение у любистока лекарственного начинается в первой декаде июля, у морковника обыкновенного - во второй декаде июля. Период цветения обоих видов в среднем составляет 35 дней. Созревание семян у любистока лекарственного начинается в конце августа, у морковника обыкновенного - в середине сентября. Результаты измерений морфологических особенностей изученных видов приведены в таблице 1. 
Таблица 1 Морфологические показатели морковника обыкновенного и любистока лекарственного

\begin{tabular}{|c|c|c|c|c|c|}
\hline \multirow{2}{*}{\multicolumn{2}{|c|}{ Параметр }} & \multicolumn{2}{|c|}{ Silaum silaus } & \multicolumn{2}{|c|}{ Levisticum officinale } \\
\hline & & $\mathrm{M} \pm \mathrm{m}$ & $\mathrm{C}_{\mathrm{v}}, \%$ & $\mathrm{M} \pm \mathrm{m}$ & $\mathrm{C}_{\mathrm{v}}, \%$ \\
\hline \multicolumn{2}{|l|}{ Высота растения, см } & $123,6 \pm 1.31$ & 2,8 & $168,4 \pm 0,87$ & 1,4 \\
\hline \multicolumn{2}{|l|}{ Толщина стебля, см } & $0,7 \pm 0,02$ & 7,2 & $1,7 \pm 0,05$ & 9,7 \\
\hline \multicolumn{2}{|c|}{ Длина прикорневых листьев с черешком, см } & $58,6 \pm 1,72$ & 7,8 & $67,4 \pm 2.19$ & 8,6 \\
\hline \multicolumn{2}{|c|}{ Ширина прикорневых листьев, см } & $15,6 \pm 0,43$ & 7,3 & $24,7 \pm 0,57$ & 6,1 \\
\hline \multicolumn{2}{|c|}{ Длина стеблевых листьев с черешком, см } & $32,4 \pm 0,84$ & 6,9 & $31,6 \pm 0,38$ & 12,6 \\
\hline \multicolumn{2}{|c|}{ Ширина стеблевых листьев, см } & $17,0 \pm 0,38$ & 5,9 & $12,6 \pm 0,30$ & 6,3 \\
\hline \multicolumn{2}{|c|}{ Число прикорневых листьев, шт. } & $45,7 \pm 0,94$ & 5,5 & $15,9 \pm 0,96$ & 16,0 \\
\hline \multicolumn{2}{|c|}{ Число листьев на генеративном побеге, шт. } & $7,0 \pm 0,38$ & 14,3 & $4,3 \pm 0,18$ & 11,4 \\
\hline \multicolumn{2}{|c|}{ Число генеративных побегов, шт. } & $10,0 \pm 0,38$ & 10,0 & $3,4 \pm 0,20$ & 15,6 \\
\hline \multirow{2}{*}{$\begin{array}{l}\text { Число зонтиков } \\
\text { на генеративном побеге, шт. }\end{array}$} & I пор. & $6.1 \pm 0.40$ & 17,4 & $8,3 \pm 0,42$ & 13,4 \\
\hline & II пор. & $15,4 \pm 0,72$ & 12,3 & $16,1 \pm 1,20$ & 19,7 \\
\hline \multirow{2}{*}{$\begin{array}{l}\text { Число зонтичков } \\
\text { в зонтике, шт. }\end{array}$} & I пор. & $14,0 \pm 0,62$ & 11,7 & $14,1 \pm 0,40$ & 7,6 \\
\hline & II пор. & $11,0 \pm 0,31$ & 7,4 & $10,6 \pm 0,20$ & 5,1 \\
\hline \multirow{2}{*}{ Диаметр зонтика, см } & I пор. & $4,3 \pm 0,07$ & 4,2 & $5,3 \pm 0,08$ & 3,7 \\
\hline & II пор. & $1,8 \pm 0,04$ & 5,4 & $2,1 \pm 0,08$ & 10,3 \\
\hline \multirow{2}{*}{$\begin{array}{l}\text { Число цветков } \\
\text { в зонтике, шт. }\end{array}$} & I пор. & $17,6 \pm 0,37$ & 5,6 & $27,4 \pm 0,53$ & 5,1 \\
\hline & II пор. & $13,4 \pm 0,43$ & 8,4 & $14,9 \pm 1,08$ & 19,2 \\
\hline \multirow{2}{*}{$\begin{array}{l}\text { Диаметр зонтичка } \\
\text { в зонтике, см }\end{array}$} & I пор. & $0,5 \pm 0,02$ & 9,8 & $1,0 \pm 0,04$ & 10,0 \\
\hline & II пор. & $0,3 \pm 0,02$ & 16,3 & $0,4 \pm 0,02$ & 15,1 \\
\hline
\end{tabular}

Морковник обыкновенный в природе встречается в Скандинавии и других странах Европы. В России - в степных и лесостепных районах южной полосы европейской части, на Кавказе, в Сибири. В Республике Башкортостан встречается в степях, на солончаках, солонцах, среди степных кустарников, окраинах полей, вдоль дорог $[1,9]$. Это многолетнее травянистое растение, которое в условиях культуры в ботаническом саду г. Уфы достигает высоты 123,6 \pm 1,31 см. Листья трижды и четырежды перисторассеченные, в очертании яйцевидные. Прикорневые листья крупные на длинных черешках, $58,6 \pm 1,72$ см длиной и $15,6 \pm 0,43$ см шириной. Стеблевые листья более мелкие, $32,4 \pm 0,84 \mathrm{~cm}$ длиной и $17,0 \pm 0,38$ см шириной, менее рассеченные. Прикорневые листья многочисленные $(45,7 \pm 0,94$ шт.) по сравнению со стеблевыми (7,0 \pm 0,38 шт.). Цветы мелкие бледно-желтые, собраны в сложные зонтики. Любисток лекар- ственный произрастает в горах южной части Ирана, почти по всей Европе и Северной Америке. В одичавшем виде встречается на Кавказе и европейской части России, в Башкортостане [10].

Многолетнее травянистое растение, в культуре достигает $168,4 \pm 0,87$ см высоты. Стебель прямой, полый, голый, бороздчатый, вверху ветвистый, толщиной $1,7 \pm 0,05$ см. Листья перисторассеченные, темно-зеленые, блестящие. Нижние листья крупные $(67,4 \pm 2,19$ см длиной и $24,7 \pm 0,57$ см шириной) на длинных черешках, стеблевые листья сидячие, влагалищные, $31,6 \pm 0,38$ см длиной и $12,6 \pm 0,30$ см шириной. Цветки беловато-желтоватые, собраны в соцветие - сложный зонтик. Из двух изученных видов пряно-ароматических растений любисток лекарственный отличается более высокими показателями по высоте растений и толщине стебля, но при этом он образует почти в три раза меньше прикорневых листьев и генеративных побегов.

Таблица 2 Оценка успешности интродукции

\begin{tabular}{|l|c|c|c|c|c|c|c|c|c|}
\hline \multicolumn{1}{|c|}{ Вид } & $\begin{array}{c}\text { Интенсив- } \\
\text { ность пло- } \\
\text { доношения }\end{array}$ & $\begin{array}{c}\text { Всхо- } \\
\text { жесть } \\
\text { семян }\end{array}$ & $\begin{array}{c}\text { Семенное } \\
\text { размноже- } \\
\text { ние }\end{array}$ & $\begin{array}{c}\text { Вегетатив- } \\
\text { ное раз- } \\
\text { множение }\end{array}$ & $\begin{array}{c}\text { Габитус } \\
\text { в куль- } \\
\text { туре }\end{array}$ & $\begin{array}{c}\text { Повреждаемость } \\
\text { болезнями } \\
\text { и вредителями }\end{array}$ & $\begin{array}{c}\text { Зимо- } \\
\text { стой- } \\
\text { кость }\end{array}$ & $\begin{array}{c}\text { Сумма } \\
\text { баллов }\end{array}$ & $\begin{array}{c}\text { Перспек- } \\
\text { тивность }\end{array}$ \\
\hline Silaum silaus & 3 & 3 & 3 & 3 & 3 & 3 & - & 21 & ОП \\
\hline Levisticum officinale & 3 & 3 & 3 & 3 & 3 & 3 & 3 & 21 & ОП \\
\hline
\end{tabular}

Примечание: ОП- очень перспективные. 
Морфологические показатели характеризуются нормальной степенью варьирования (от 1,4 до 19,7 \%). Для оценки успешности интродукции нами по трехбалльной системе оценивались семь признаков растений. Балл 1 - наихудшее состояние, балл 3 - наилучшее. По суммарной оценке виды отнесены к группе очень перспективных (ОП - 18-21 баллов) и их можно рекомендовать для широкого использования в качестве пряного сырья.

Выводы. В результате интродукции морковника обыкновенного и любистока лекар- ственного нами выявлено, что в условиях Башкирского Предуралья они проходят полный цикл своего развития, ежегодно цветут, плодоносят, завязывая полноценные семена. Могут быть рекомендованы к использованию в качестве сырья в некоторых отраслях пищевой промышленности и кулинарии, а также в ликероводочном производстве.

Работа выполнена в рамках государственного задания ЮУБСИ УФИЦ РАН по теме № AAAA-A18-118011990151-7.

\section{Библиографический список}

1. Машанов, В.И. Пряно-ароматические растения [Текст] / В.И. Машанов, А.А. Покровский. М.: Агропромиздат, 1991. С. 184-187.

2. Поляков, В.А. Плодово-ягодное и растительное сырьё в производстве напитков [Текст] / В.А. Поляков, И.И. Бурачевский, А.В. Тихомиров и др. М.: ДеЛи плюс, 2011. С. 105-106.

3. Кадильникова, Е.И. Климат района г. Уфы. Записки Башкирского филиала Географического общества СССР [Текст] / Е.И. Кадильникова. Уфа, 1960. С. 61-71.

4. Бейдеман, И.Н. Методика изучения фенологии растений и растительных сообществ [Текст] / И.Н. Бейдеман. Новосибирск: Наука, 1974. $155 \mathrm{c}$.

5. Трулевич, Н.В. Эколого-фитоценотические основы интродукции растений [Текст] / Н.В. Трулевич. М.: Наука, 1991. 216 с.
6. Зайцев, Г.Н. Математика в экспериментальной ботанике [Текст] / Г.Н. Зайцев. М.: Наука, 1990. 296 с.

7. Карписонова, Р.А. Редкие виды травянистых растений широколиственных лесов СССР в Главном ботаническом саду [Текст] / Р.А. Карписонова // Бюлл. ГБС АН СССР. 1979. Вып. 112. C. $54-59$.

8. Томилова, Л.И. Эндемики флоры Урала в Ботаническом саду в Свердловске [Текст] / Л.И. Томилова // Бюлл. ГБС. 1982. Вып. 126. C. 25-31.

9. Определитель высших растений Башкирской АССР [Текст]. М.: Наука, 1989. С. 165166.

10. Воронина, Е.П. Новые ароматические растения для Черноземья [Текст] / Е.П. Воронина, Ю.Н. Горбунов, Е.О. Горбунова. М.: Наука, 2001. С. 64-67.

\section{Сведения об авторах}

1. Анищенко Ирина Евгеньевна, кандидат биологических наук, ведущий научный сотрудник лаборатории дикорастущей флоры и интродукции травянистых растений Южно-Уральского ботанического сада-института УФИЦ РАН, 450080, Республика Башкортостан, г. Уфа, ул. Менделеева, д. 195/3, тел.: (347) 286-12-55, e-mail: irina6106@mail.ru.

2. Жигунов Олег Юрьевич, кандидат биологических наук, старший научный сотрудник лаборатории дикорастущей флоры и интродукции травянистых растений Южно-Уральского ботанического сада-института УФИЦ РАН, 450080, Республика Башкортостан, г. Уфа, ул. Менделеева, д. 195/3, тел.: (347) 286-12-55, e-mail: zhigunov2007@yandex.ru.

3. Иибирдина Лилия Маратовна, кандидат биологических наук, доцент кафедры лесоводства и ландшафтного дизайна, ФГБОУ ВО Башкирский ГАУ, 450001, Республика Башкортостан, г. Уфа, ул. 50-летия Октября, д. 34, тел.: (347) 228-68-11.

В настоящей работе представлены результаты изучения особенностей сезонного ритма роста и развития, морфометрических показателей и оценки успешности интродукции двух малоиспользуемых пряно-ароматических видов семейства Apiaceae - Silaum silaus (морковник обыкновенный) и Levisticum officinale (любисток лекарственный) в условиях культуры. Исследования проводились в Южно-Уральском ботаническом саду. Весеннее отрастание у Silaum silaus и Levisticum officinale происходит в конце апреля, в фазу бутонизации растения 
вступают во второй декаде июня, массовое цветение у любистока лекарственного начинается в первой декаде июля, у морковника обыкновенного - во второй декаде июля. Период цветения обоих видов в среднем составляет 35 дней. Созревание семян у любистока лекарственного начинается в конце августа, у морковника обыкновенного - в середине сентября. Из двух изученных видов пряно-ароматических растений любисток лекарственный отличается более высокими показателями по высоте растений и толщине стебля, но при этом он образует почти в три раза меньше прикорневых листьев и генера- тивных побегов. Морфологические показатели характеризуются нормальной степенью варьирования (от 1,4 до 19,7 \%). В результате интродукции морковника обыкновенного и любистока лекарственного нами выявлено, что в условиях Башкирского Предуралья они проходят полный цикл своего развития, ежегодно цветут, плодоносят, завязывая полноценные семена. Могут быть рекомендованы к использованию в качестве сырья в некоторых отраслях пищевой промышленности и кулинарии, а также в ликероводочном производстве.

I. Anishchenko, O. Zhigunov, L. Ishbirdina

\title{
RARELY USED AROMATIC PLANTS IN THE BASHKIR CIS-URALS
}

\begin{abstract}
Key words: aromatic plants; morphometric parameters; seasonal rhythm of development; success of introduction.
\end{abstract}

\section{Authors' personal details}

1. Anishchenko Irina, Candidate of Biological Sciences, Leading Researcher of the laboratory of wildgrowing flora and herbaceous plant introduction, South-Ural Botanical Garden-Institute of Ufa Federal Research Center of Russian Academy of Sciences, 450080, Bashkortostan, Ufa, Mendeleev St., 195/3, phone: (347) 286-12-55, e-mail: irina6106@mail.ru.

2. Zhigunov Oleg, Candidate of Biological Sciences, Senior Researcher of the laboratory of wild-growing flora and herbaceous plant introduction, South-Ural Botanical Garden-Institute of Ufa Federal Research Center of Russian Academy of Sciences, 450080, Bashkortostan, Ufa, Mendeleev St., 195/3, phone: (347) 286-12-55, e-mail: zhigunov2007@yandex.ru.

3. Ishbirdina Liliya, Candidate of Biological Sciences, Associate Professor of Forestry and Landscaping Department, Federal State Budgetary Educational Institution of Higher Education «Bashkir State Agrarian University», 450001, Bashkortostan, Ufa, 50-letiya Oktyabrya St., 34, phone: (347) 228-68-11.

Two rarely used aromatic species of the Apiaceae family - Silaum silaus and Levisticum officinale in their habitat were studied. Features of their seasonal growth and development rhythm, morphometric indicators were considered, success of the plant introduction was measured. The study was conducted in the South Ural botanical garden. Silaum silaus and Levisticum officinale both have spring aftergrowing at the end of April, budding in the second ten-day period of June; Levisticum officinale starts to blossom in the first ten-day period of July, while Silaum silaus starts to bloom in the second ten-day period of July. The blooming period of both plants averages 35 days. Seeds of Levisticum officinale begin to mature at the end of August, while seeds of Silaum silaus start ripening in the middle of September. In comparison to the second species Levisticum officinale features higher rates in height and stalk thickness, however, the plant forms three times fewer bottom leaves and generative shoots. Morphological indicators have standard variation rates (from 1,4 to $19,7 \%$ ). The introduction of Silaum silaus and Levisticum officinale revealed that in the Bashkir Cis-Urals the plants complete the development cycle, that is, blossom, give yield, set full seeds. The study plants can be recommended for use as raw materials in food production, cooking and alcoholic beverage production.

(C) Анищенко И.Е, Жигунов О.Ю., Ишбирдина Л.М. 